\title{
電磁石による鋼板形状制御時の安定性に関する考察*
}

\author{
井上淳 司*1, 藤 岡 宏 規*2 \\ 森 井茂 樹*3, 小森 望 充*4

\section{Study on Stability of Steel Strip Under the Electromagnetic Shape Controller}

\author{
Atsushi INOUE*5, Hironori FUJIOKA, \\ Shigeki MORII and Mochimitsu KOMORI \\ ${ }^{* 5}$ MITSUBISHI HEAVY INDUSTRIES, LTD., HIROSHIMA R \& D CENTER, \\ 4-6-22 Kan-on-shin-machi, Nishi-ku, Hiroshima-shi, Hiroshima, 733-8553 Japan
}

\begin{abstract}
In a steel process line, shape controller of steel strip which use an electromagnet are important devices which improve strip quality and line speed. It is confirmed that the devices are beneficial when these are applied to continuous galvanizing line (CGL). However, it is necessary to avoid a static instability phenomenon by the negative spring of the electromagnet, and a spill-over phenomenon to be caused by the high gain of the control system in this device. We proposed the analysis model combining the control system with the steel strip. The model was applied to a real machine to confirm the availabilities. Moreover, this paper discusses the static instability phenomenon and the spill-over phenomenon.
\end{abstract}

Key Words : Flexible Structure, Vibration Control Device, Electromagnetic Induce Vibration

\section{1. 緒 言}

製鉄プロセスラインでは，熱処理による鋼板強度の 向上や亜鉛メッキ等の表面処理を行い, 鋼板の付加価 值を高める. そこでは，品質の向上と共に操業効率の 向上が望まれている.

例えば図1に示す連続溶融亜鉛メッキライン(CGL： Continuous Galvanizing Line) においては，悪鉛付着量 を調整するワイピングノズル位置で，鋼板にそり等の 板幅方向の変形及び振動があると要鉛付着量にバラツ キが生じ，表面処理の品質が低下する(1)(2)。また，品 質（目付量）を確保するため厚めに目付を行い，無駄 な亜鉛を消費している．このため付着量均一化による 亜鉛消費量の低減も望まれている．しかしながら，メ

* 原稿受付 2008 年 1 月 7 日.

*1 正員, 三菱重工業(株)広島研究所(雪733-8553 広島市西区 観音新町 4-6-22).

*2 三菱日立製鉄機械(株) (画733-8553 公島市西区観音新町 46-22).

*3 正員, MHIソリューションテクノロジーズ(株) (画 7338553 広島市西区観音新町 4-6-22).

*4 正員, 九州工業大学工学研究科( ( 804-8550 北九州市戸畑 区仙水町 1-1).

E-mail : atsushi_inoue@mhi.co.jp
ッキ直後の鋼板は亜鉛が凝固していないためロールで 支持することが出来ず，かつ品質向上を図る様々な処 理を行うため，搬送ロールの間隔が大きくなり，鋼板 のそりが発生しや寸い状況にある.

そこで，悪鉛メッキ鋼板の目付量を調整するワイピ ングノズル近傍で，そり量を低减する銅板形状制御装 置を開発した ${ }^{(3)}$. 電磁石をアクチュエータとする本装置 は, 磁気軸受や磁気浮上装置で用いた非接触位置決め および振動制御技術が適用されている. 電磁石の使用 により，電磁石の負のばねによる静的不安定現象，あ るいは制御系の高ゲインに起因するスピルオーバ現象 を回避する必要があり, これまでに, 磁気軸受の弾性


回避方法が研究されている. 本報では，実際のCGLに 本装置を設置し, 張力を与えた鋼板を電磁石で位置決 め制御を行う際の不安定現象を対象とする. 張力を与 えた鋼板と電磁石をアクチュエータとする制御系を連 成させた解析モデルを作成し, 静的不安定およびスピ 
ルオ一バ現象を解析し，かつ回避方法について考察し た結果を報告する．

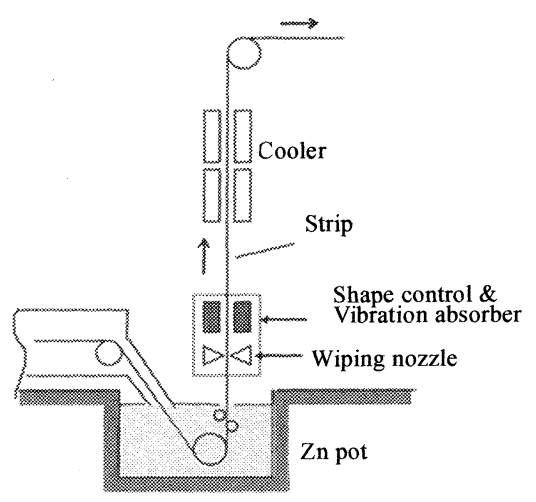

Fig. 1 Device arrangement in CGL

\section{2. 製鉄プロセスラインに於ける装置構成}

ワイピングノズルでは，覀鉛が付着した鋼板に向か つて高速にエア一を吹き付けることで余分な亜鉛を择 き落とす. そこで，ワイピングノズル位置で銅板のそ りを抑えることによって亜鉛の付着量均一化を図るた め, 図 2 に示すようにワイングノズル付近に本装置を 設置した。本解析に用いた装置の仕様を表 1 に示す.

本装置は鋼板の変位をセンサで計測し，目標值との 偏差信号を制御部に送り，鋼板を目標位置に追従させ るため, 鋼板の両面に設置した電磁石を駆動させる. この装置を板幅方向に複数台設置し, 板幅方向全般に 於いてそりを低減することが出来る.

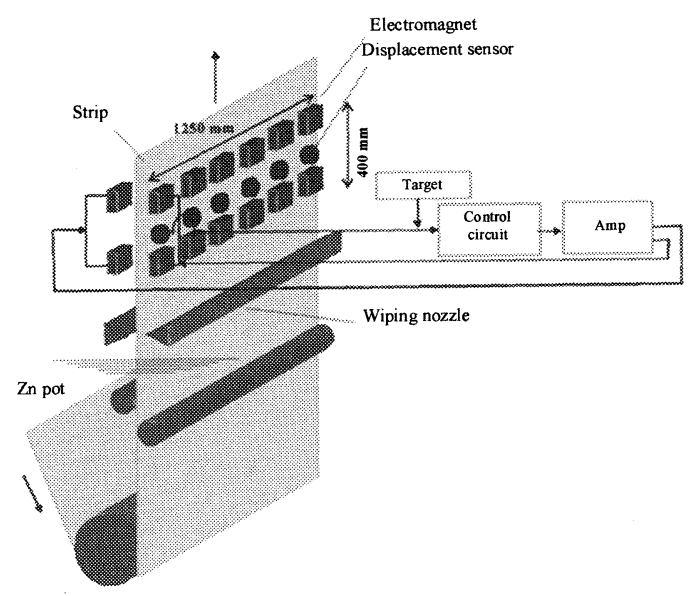

Fig. 2 Device for CGL
Table 1 Specifications of shape control \& vibration absorber

\begin{tabular}{|l|l|}
\hline \multicolumn{1}{|c|}{ Device } & \multicolumn{1}{c|}{ Specifications } \\
\hline Displacement sensor & Range/volt $: 25 \mathrm{~mm} / 5 \mathrm{~V}$ \\
\hline Control circuit & DSP computing speed : 0.4msec \\
\hline Amplifier & Rated output current $: 7.2 \mathrm{~A}$ \\
\hline Electromagnet & $\begin{array}{l}\text { Magnetic force }: 49 \mathrm{~N} / \text { each at } 3.9 \mathrm{~A} \\
\text { Distance between Steel and Magnet }: 15 \mathrm{~mm}\end{array}$ \\
\hline
\end{tabular}

\section{3. 安定性限界の解析}

3・1 解析モテル 鋼板を安定に位置決め制御 するため, 制御系と鋼板を連成させた解析を行い, 安 定限界の把握および，不安定現象の回避を行う. 図 3 はCGLに本装置を設置し, 張力を与えた鋼板と制御系 を連成させたモデルである. 通常板幅は 900〜 $1800 \mathrm{~mm}$ に対し，ロール間の長さが 14〜 $50 \mathrm{~m}$ 程度あるため, 板 幅方向を無視し, 張力の作用した弦モデルとして取り 扱う。電磁石を用いたフィードバック制御系の鋼板へ の作用は，周波数特性を有するばねおよび減衰器とし てモデル化する．また，実際の製鉄ラインにおける鋼 板は $100 \mathrm{~m} / \mathrm{min}$ 程度の速さで搬送されるが, 鋼板の振 動特性への影響を無視出来る搬送速度であり，鋼板は 静止状態でモデル化した.

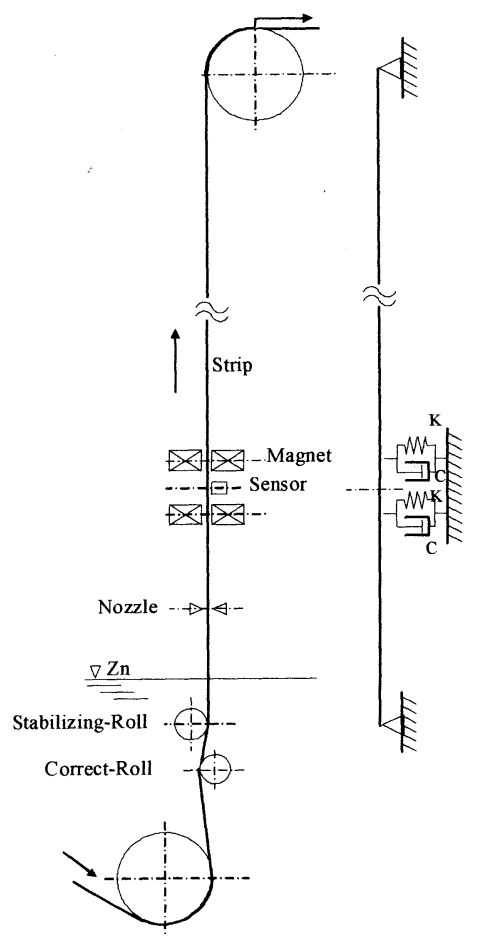

Fig. 3 Strip model 
まず，張力作用させた鋼板を一様弾性棒として有限 要素の定式化を行う. 図 4 は要素の長さ $l$, 両端の節 点番号を 1,2 とし, 両端に作用する張力を $T$, 両端 のたわみ量および回転角を $u_{1}, u_{2}, \varphi_{1}, \varphi_{2}$ ，要素の両端に 作用する外力とモーメントを $V_{1}, V_{2}, T_{1}, T_{2}$ で表すと, 本 要素の運動方程式は式(1)のように与えられる(7).

$$
\begin{aligned}
& {[m]\{\dot{\xi}\}+[c][\dot{\xi}\}+[k]\{\xi\}=\left\{f_{\xi}\right\} } \\
& \beth こ て ゙ \\
&\{\xi\}=\left(u_{1}, \varphi_{1}, u_{2}, \varphi_{2}\right)^{T} \\
&\left\{f_{\xi}\right\}=\left(V_{1}, T_{1}, V_{2}, T_{2}\right)^{T}
\end{aligned}
$$

ただし， $[m]$ は質量行列， $[c]$ は減衰行列， $[k]$ は風性 行列を表し，それぞれ式(2)〜式(4)示寸対称行列となる. 張力を与えた鋼板では, 式(4)に示才岡性行列において

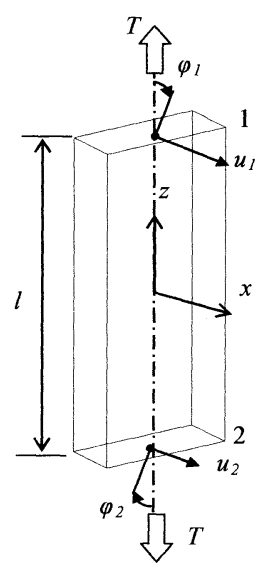

Fig. 4 Uniform flexible beam 弾性棒の持つ材料力学的な岡性に, 第 2 項に示す張力 $T$ が作用することで発生する剛性を加える.

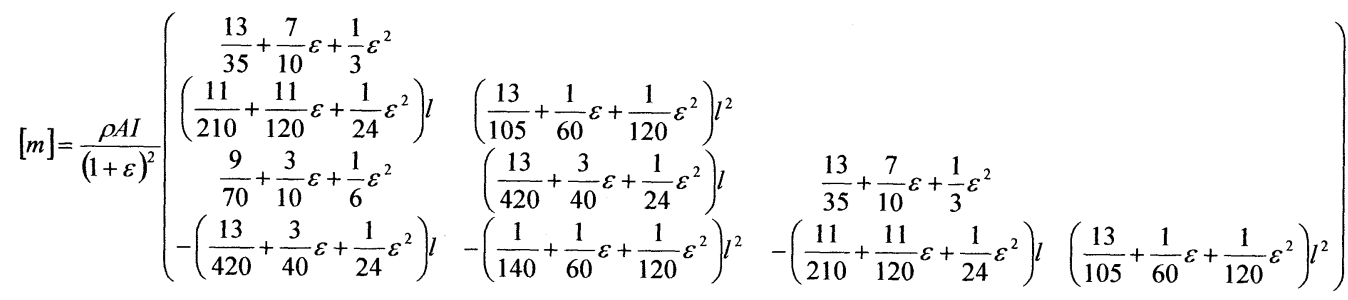

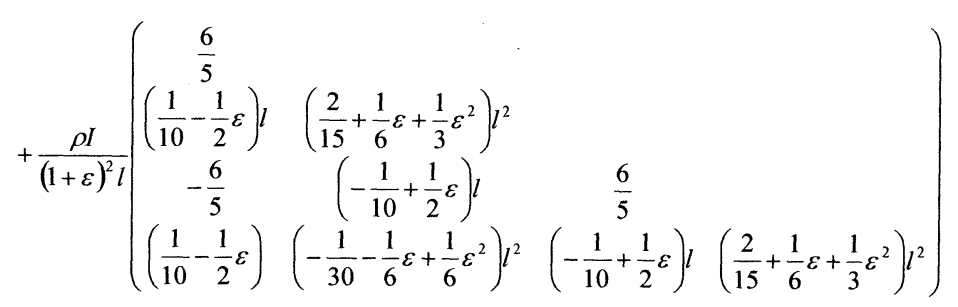

$[C]=\beta[k]$

$[k]=\frac{E I}{(1+\varepsilon) l^{3}}\left(\begin{array}{cccc}12 & & \\ 6 l & (4+\varepsilon) l^{2} & \\ -12 & -6 l & 12 \\ 6 l & (2-\varepsilon) l^{2} & -6 l & (4+\varepsilon) l^{2}\end{array}\right)+\left(\begin{array}{cccc}\frac{T}{l} & 0 & -\frac{T}{l} & 0 \\ 0 & 0 & 0 & 0 \\ -\frac{T}{l} & 0 & \frac{T}{l} & 0 \\ 0 & 0 & 0 & 0\end{array}\right)$

ここで, $\rho$ は密度, $A$ は断面積, $I$ は断面二次モ一メン

卜, $E$ は縦弾性係数, $\varepsilon$ はひずみ量, $\beta$ は材料減衰係数 を表す。 
各要素の運動方程式を用いることで, 有限要素法の手 順に従い，鋼板全体の運動方程式が式(5)の通り組み立 てられる(7).

$$
[M]\{\ddot{X}\}+[C]\{\dot{X}\}+[K]\{X\}=\{F\}
$$

$$
\text { ここで }
$$

$$
\{X\}=\left(u_{1}, \varphi_{1}, u_{2}, \varphi_{2}, \ldots \ldots \ldots . . . \quad\right)^{T}
$$

式(5)の右辺は外力の作用を表し, 本装置の場合電磁石 をアクチュエータとする鋼板変位に応じた吸引力が働 $<$.

3 - 2 制御特性のモデル化 鋼板の位置決め制 御は, 鋼板の変位信号と目標值の差分をとり, 制御回 路を通して鋼板の両側設置した電磁石を駆動させるこ とで実施する．制御のブロック線図を図 5 に示す.

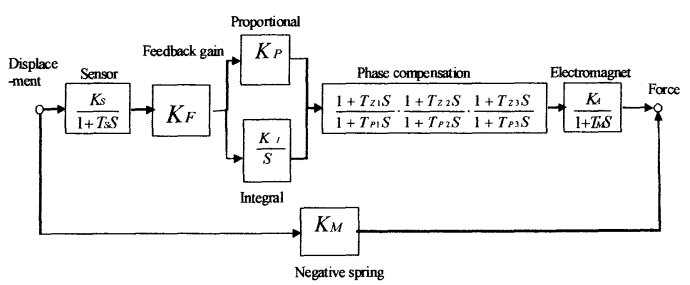

Fig. 5 System and block diagram

制御方式は $P$ (比例),$I$ (積分）之位相補償回路の 直列結合である. センサと電磁石は遅れ系であり, 减 衰性を作用させるため位相補償回路を設けている．鋼 板に作用する吸引力を表すため, ラプラス変換後の鋼 板の変位 $U(s)$ と吸引力 $F(s)$ との伝達関数 $B(s)$ を 式(6)の通り表し, 制御系の動特性を考える.

$$
B(s)=\frac{F(s)}{U(s)}
$$

鋼板の変位 $U(s)$ に対して, 電磁石を含む制御系は 次の受動部特性と能動部特性を持つ. 受動部特性 $F_{M}(s)$ は式(7)で表され, 制御特性に関係なく変位に 応じて電磁石に鋼板が吸引される力である.

$$
F_{M}(s)=K_{M} \cdot U(s)
$$

ここで， $K_{M}[\mathrm{~N} / \mathrm{m}]$ は電磁石の受動特性を表す.これ は図 2 に示すように鋼板の両側に電磁石を配置し, バ イアス電流を印加する. 磁気軸受と同様に, この状態
から鋼板が変位した際に，変位方向一鋼板を吸引する 力が発生し，式(8)に示すようにばね定数として表す.

$$
K_{M}=-4 K_{T} \frac{i_{B}{ }^{2}}{\delta_{\mathrm{g}}{ }^{3}}
$$

$K_{T}\left[\mathrm{~N}(\mathrm{~m} / \mathrm{A})^{2}\right]$ は電磁石定数, $i_{B}[\mathrm{~A}]$ はバイアス電流, $\delta_{8}[\mathrm{~m}]$ は鋼板之電磁石の距離を表す.

また能動部特性 $F_{A}(s)$ は鋼板の変位に応じ制御系を 介して銅板に作用する吸引力で, 図5 のセンサから電 磁石までの伝達特性として式(9)で表すことが出来る.

$$
\begin{aligned}
F_{A}(s) & =\frac{K_{s}}{1+T_{s} \cdot s} \cdot K_{F} \cdot\left(K_{P}+\frac{K_{I}}{s}\right) \\
& \cdot \frac{1+T_{Z 1} \cdot s}{1+T_{P 1} \cdot s} \cdot \frac{1+T_{Z 2} \cdot s}{1+T_{P 2} \cdot s} \cdot \frac{1+T_{Z 3} \cdot s}{1+T_{P 3} \cdot s} \cdot \frac{K_{A}}{1+T_{M} \cdot s}
\end{aligned}
$$

ここで, $K$ は各要素のゲイン, $T$ は時定数を表す.な お $K_{A}[\mathrm{~N} / \mathrm{A}]$ は電磁石の能動的特性であり式(10)で表 す. 電磁石の能動特性 $K_{A}$ は, 受動特性 $K_{M}$ 之同様にバ イアス電流を印加した電磁石を鋼板の両側に配置し, 鋼板が変位した際，目標位置へ鋼板を戻すために電磁 石に制御電流が流れ，この電流で発生する吸引力を表 したものである.

$$
K_{A}=4 K_{T} \frac{i_{B}}{\delta_{\mathrm{g}}{ }^{2}}
$$

以上が図 5 に示寸制御ブロック線図の動特性である.

次に式(6) $s=j 2 \pi f$ を代入すると, 周波数 $f$ に依 存した制御系の複素動剛性が式(11)で表せる.

$$
b(f)=B(j 2 \pi f)=b_{R}(f)+j b_{I}(f)
$$

ここで，添字の $R$ は実部を $I$ は虚部を示し，これをナ イキスト線図に描いたものを図6に示す。これは鋼板 変位に応じた電磁石の吸引力特性でもあり, 式(6)を介 して鋼板への外力として鋼板の運動方程式(5)一代入 し次の通り表すことが出来る.

$$
\begin{aligned}
{[M]\{\ddot{X}\}+[C} & \left.+\frac{1}{2 \pi f} b_{I}(f)\right]\{\dot{X}\} \\
& +\left[K+b_{R}(f)\right]\{X\}=0
\end{aligned}
$$

鋼板への作用は図 6 のナイキスト線図で示すよう に, $0.1 \mathrm{~Hz}$ 以下の低周波数域では電磁石の受動的特性 に起因する静的不安定現象が発生する. $0.1 \sim 20 \mathrm{~Hz}$ の 
領域は減衰性を有し制振効果を有する領域であり，こ の領域に鋼板の固有振動数の 1 次成分を入れるよう にする. また外乱による鋼板の振動成分もカバーさせ る. $20 \mathrm{~Hz}$ 以上の高周波数域では再び不安定域となる. この領域の励振力は比例と位相補償によって決まり， 無数の固有振動数が存在することでそれらが励起さ れ，スピルオーバ現象が発生する可能性がある.

さらに電磁石が有限の幅を持つために, 電磁石位置 に於いて鋼板の回転角に対して式(13)で表せる受動的 な回転ばね $K_{\theta}[\mathrm{Nm} / \mathrm{rad}] か ゙$ 発生する。これは制御時の 安定性に影響を与えるものであり, 式(12)の剛性行列 に加える.

$$
K \vartheta=-\frac{1}{12} K_{M} \cdot d^{2}
$$

ここで, $d[\mathrm{~m}]$ は電磁石の鋼板長手方向の幅を表す．

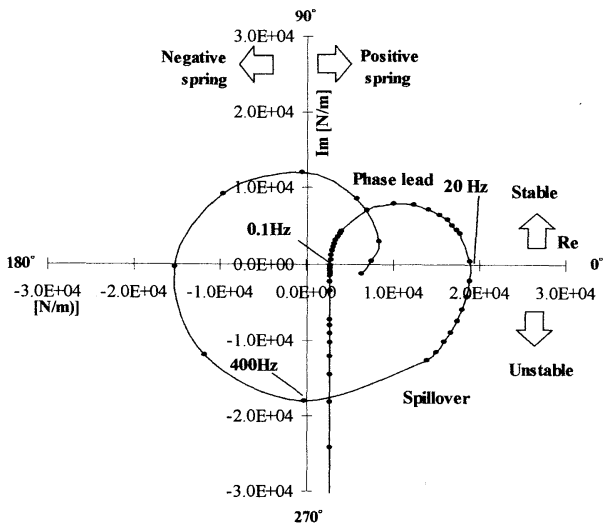

Fig. 6 Nyquist plot (Frequency character of feedback system)

3-3 静的安定性解析結果 本装置に於ける静 的不安定現象は, 図6で示した低周波数の領域で,「張 力を与えた鋼板の剛性十制御で与える剛性」<

「電磁石の負剛性」の条件が成り立つ際に発生する. そこで鋼板と制御系を連成させた有限要素法にて鋼 板に与えた張力と図 5 に示寸制御系のフィードバッ クゲインをパラメータに式(12)を用いて固有值解析 を行った ${ }^{(8)}$. 図 7 は鋼板の長さ $14.9 \mathrm{~m}$, 板幅 $1250 \mathrm{~mm}$, 板厚 $0.8 \mathrm{~mm}$ の条件で板幅方向に 6 軸の電磁石を配置 し, 表 1 に示寸装置仕椂で解析した振動モードの一例 である. フィードバックゲイン 0.2 は減衰比が正で安 定であり，マグネット位置で節となるモードを示す. これに対しフィードバックゲインを低くした 0.025 で は静的不安定となり, 電磁石に鋼板が吸い付くモード
を示し，減衰比も負となり不安定であることを示して いる.

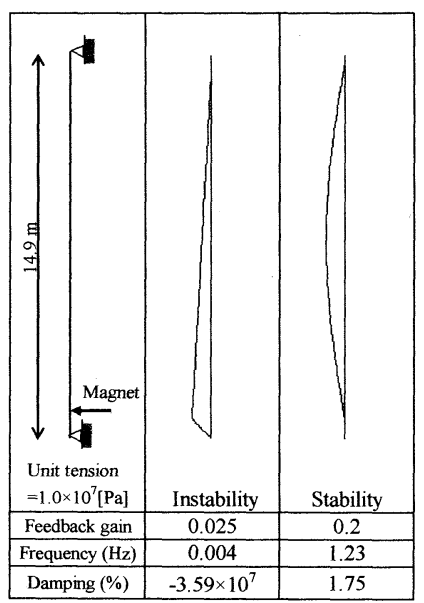

Fig. 7 Modal analysis results static instability

鋼板に与えた張力と制御系のフィードバックゲイン をパラメータとした解析結果を図8に示寸，正常に制 御し安定な状態では, 式(14)に示す張力を与えた弦の 固有振動数にほぼ等しい值となる.

$$
f=\frac{n}{2 L} \sqrt{\frac{\sigma}{\rho}}
$$

ここで， $\sigma[\mathrm{Pa}]$ は鋼板に作用するユニット張力， $\rho$ $\left[\mathrm{kg} / \mathrm{m}^{3}\right]$ は鋼板の材料密度, $L[\mathrm{~m}]$ は両端を支持され た鋼板の長さ, $n$ は固有振動数の次数を表す.

正常な制御の状態からフィードバックゲインを低く すると，図7に示す安定状態の振動モードから，電磁 石に鋼板が吸い付くモードに移行し，固有振動数がほ ぼ $0 \mathrm{~Hz}$ となり，減衰比も負の值を示す。これ以下の> イードバックゲインでは, 電磁石の負剛性が, 鋼板と 制御系の剛性に勝り, 静的不安定を起こす. また薄板 鋼板の岡性は張力で決まるため, 張力が高いほど低い フィードバックゲインでも安定となる.

静的不安定の一例として実際の CGL に適用した際 の実験結果を図 9 に示す. 板幅方向に 6 軸の電磁石で 制御しており Ch1〜Ch6 は各軸のセンサで計測した鋼 板の変位である. 制御のフィードバックゲインを低く したことによって，目標位置へ鋼板が移動するが，安 定に位置決めできず電磁石に鋼板が吸い付けられる. 吸い付けられ目標值から外れたことで, 制御系が作用 し反対側の電磁石へ電流が流れ反対側の電磁石に鋼板 が吸い付けられる.この動作を繰り返す不安定現象で 
ある. 安定化のためには，図8に示すように，各張力 に対する安定限界を解析にて把握し，フィードバック ゲインの最低值を設定する必要がある.

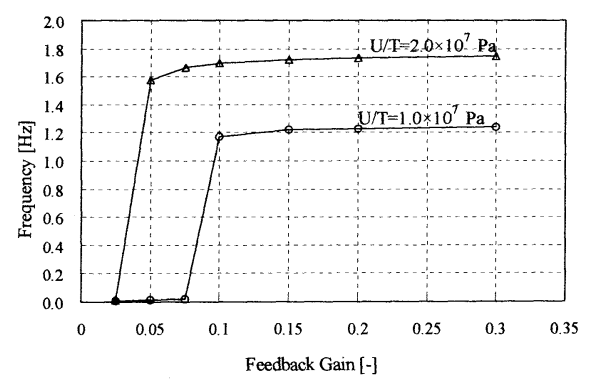

(a) Natural frequency

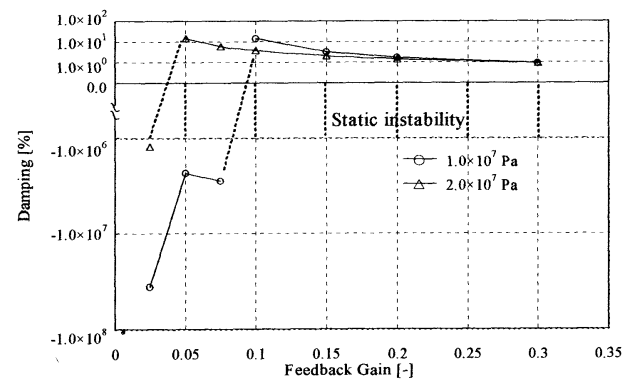

(b) Damping ratio

Fig. 8 Static instability analytical result

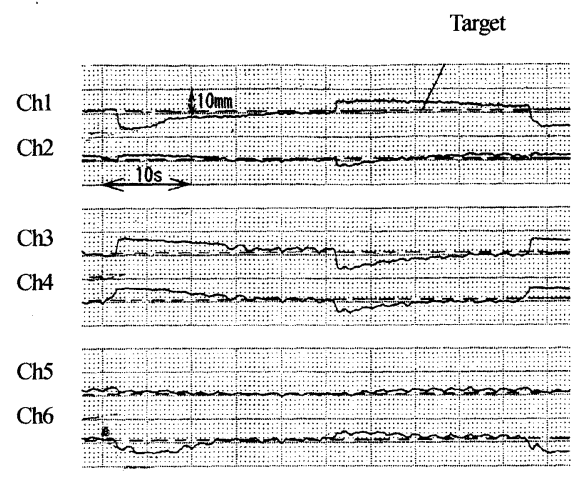

Fig. 9 Static instability phenomena

3-4 動的安定性 (スピルオ一パ) 解析結果 図 3 に示寸解析モデルを使い, 制御系のフィードバック ゲインを過度に高くすることで発生するスピルオ一バ 現象を解析した. スピルオーバ現象は図 6 の周波数特 性で位相補償領域より高い周波数域 (図6 の場合 $20 \mathrm{~Hz}$
以上）で鋼板の固有振動数成分が制御系によって励起 される現象である. 静的安定限界と同じ銅板条件で行 ったスピルオーバの解析結果を図 10 に示す.鋼板の最 も低い固有振動数を 1 次とし, これから 33 次（33 番 目）の固有振動数 $40.2 \mathrm{~Hz}$ が負の减衰比 $(-0.275 \%)$ を持 ち不安定であり外乱によって発振すること，すなわち スピルオーバ現象が発生することを示している．位相 補償領域を越えた周波数域では，全ての固有振動数が 電磁石位置と鋼板の振動モード比により励振効果に差 があるが，必ず負减衰をとりスピルオ一バとなること を示す. そこで，各フィードバックゲインに於いて， 全固有振動数の負减衰最大值をプロットした結果を図 11 に示す.フィードバックゲインを上げいくことで, 負の減衰が増しよりスピルオ一バ現象が発生しやすい ことが判る．実際の製鉄プロセスラインでは，鋼板や 付属機器により減衰が作用し, 解析上負減衰となって も必ずスピルオーバが発生することはない. しかし図 11 のようにフィードバックゲインと負减衰の関係を 定量的に把握出来ることで，実測の限界值を 1 点把握 すれば，新たな設備における発生限界を予測すること が出来る。

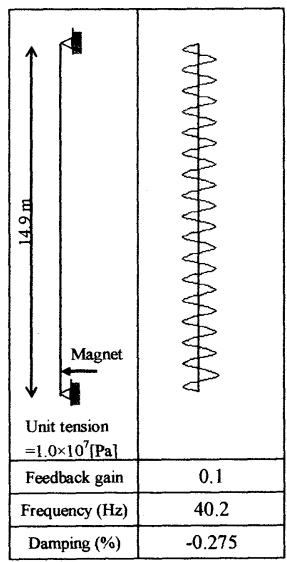

Fig. 10 Modal analysis results High-frequency instability

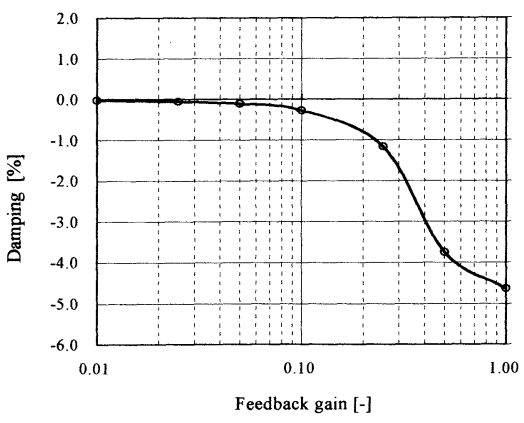

Fig.11 High-frequency instability analytical result 
図 12 は実際の製鉄ラインで過度にフィードバックゲ インを上げ，フィードバックゲイン 0.2 でスピルオー バ現象を起こした例である，制御が ONとほぼ同時に 鋼板の振動が発散的に増加する. その際に周波数分析 結果を見ると, 位相補償領域を越えた周波数 $27 \sim 60 \mathrm{~Hz}$ 付近の固有振動成分が制御系により励起されているこ とが判る.また，実際の製鉄ラインでは機器類の減衰 があるために，解析上負減衰となっても必ずスピルオ 一バが発生することはなく, フィードバックゲインを 0.2 まで上げることで初めて発生することも判った.



(a) Displacement

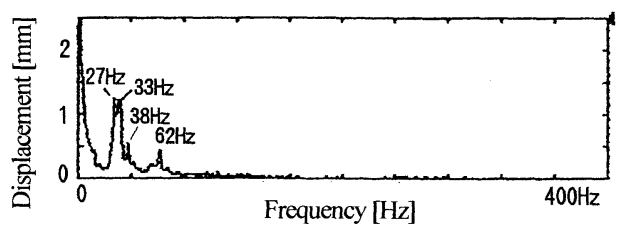

(b) Spectrum (Ch3)

Fig. 12 High-frequency instability phenomena

\section{CGLへの適用事例}

実際の製鉄ラインへ本装置を適用する際，静的不安 定やスピルオーバといった不安定現象を起こさずに稼 働させる必要がある. そのために，3章で示した解析 を行い，静的不安定によるフィードバックゲインの下 限，スピルオーバによるフィードバックゲインの上限 を設定する．また，設計段階で安定な制御定数が設定 出来るため, 実機適用時に安定限界を見極めながら制 御定数を調整する必要がなく，不安定現象（振動）を 発生させることによる鋼板と周辺機器との接触を防ぐ ことが出来る.

実際のラインへ本装置を適用した際の操業条件と使
用したフィードバックゲインを表 2 に示す. 安定に使 用出来るフィードバックゲインの範囲を拡げるため, 减衰性を有し制振効果のある領域を約 $100 \mathrm{~Hz}$ まで拡大 し，3章で示した解析方法でフィードバックゲインの 下限值と上限值を求めた. また，図 11 で示したように 減衰比が -0.8 \%を越えるとスピルオーバ現象が発生 するので，その值を取るフィードバックゲインを上限 值とした. さらに，実際に使用するフィードバックゲ インは下限值と上限值のほぼ中間値とした.

図 13 は本装置を適用した際, 本装置のセンサで計測 した鋼板の振動である. OFF の状態では本装置を使用 しておらず, $0.1 〜 5 \mathrm{~Hz}$ の周波数帯に最大 $200 \mu \mathrm{m}$ の振動 が発生している．これに対し ON の状態は本装置を使 用しており，不安定現象は発生しておらず，かつ OFF の状態で発生していた振動を十分に抑える結果も得ら れた(9).

Table 2 Operational provision \& feedback gain

\begin{tabular}{|l|c|}
\hline Roll span & $15 \mathrm{~m}$ \\
\hline Steel strip width & $908 \mathrm{~mm}$ \\
\hline Steel strip thickness & $0.9 \mathrm{~mm}$ \\
\hline Unit tension & $1.3 \times 10^{7} \mathrm{~Pa}$ \\
\hline Feedback gain lower limit & 0.2 \\
\hline Feedback gain upper limit & 3.0 \\
\hline Applied feedback gain & 1.0 \\
\hline
\end{tabular}

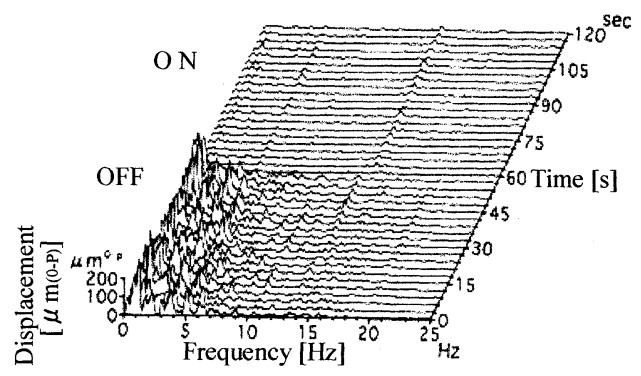

Fig. 13 Effect of application test in CGL

\section{5. まとめ}

電磁石を用いた鋼板の非接触形状制御装置において, 制御特性により発生する不安定現象について, 次の通 り解析的に予測した.

（1）張力を与えた鋼板と電磁石をアクチュエータと する制御系の連成解析モデルを作成した。

（2）同解析モデルを使い，電磁石に起因する受動部 特性と制御系の能動部特性を考慮し, 静的不安定 の発生限界を解析し, 鋼板に与えた張力と発生限 界の関係を明らかにした。 
（3）制御系のゲインを過度に高くすることで発生す るスピルオーバ現象も同解析モデルで解析を行い， スピルオーバ現象を表す負の減衰量とゲインの関 係を明らかにした。

(4) 解析モデルで求めた静的不安定とスピルオーバ の発生限界を基に制御定数を設定し, 実際の製鉄 ラインで不安定現象を起こさず安定に稼働出来 ることを確認した.

また製鉄ラインには厚さや幅の異なる鋼板が流れ， それに与える張力も変化する. 各鋼板の振動特性は異 なり, それに応じた最適な制御定数の設定と安定限界 の評価方法の確立が今後の課題である.

\section{文献}

(1) Andoh, A. et al., Recent Advance in Coated Steel Sheets, Tetsu-Hagane, Vol. 89, No.1, (2003), pp. 3-17.

(2) Tobiyama, Y. Abotani, K. Hot-Dip Galvanized Steel Sheet with Excellent Surface Quality for Automotive Outer Panels, JFE Technical report, No.4, (Nov. 2004), pp. 55-60.

(3) Morii, S. et al., Study on Shape Control and Vibration Absorber of Strip in Steel Process Line, Mitsubishi Heavy Industries Ltd. Technical Review, Vol. 32, No. 2 (May, 1995), pp. 128-131.
(4) Nonami, K. et al., Vibration and Control of a Flexible Rotor Supported by Magnetic Bearings, Transactions of the Japan Society of Mechanical Engineers, Series C, Vol. 54, No. 507(1988), pp. 2661-2688.

(5) Oshinoya, Y. et al., Electromagnetic Levitation Control of a Traveling Steel Belt, Transactions of the Japan Society of Mechanical Engineers, Series C, Vol. 57, No. 536(1991), pp. 1246-1253.

(6) Hasegawa, S. Oshinoya, Y. Ishibashi, K. Basic Examination on Elastic Vibration Control of an Electromagnetic Levitation System for Thin Steel Plate, Proceeding of the Faculty of Engineering of Tokai University, Vol. 43 No. 2 (2003), pp. 59-64.

(7) Kawashima, M. et al., Vibration Analysis of Rotor-Bearing Systems by Finite Element Method, Mitsubishi Heavy Industries Ltd. Technical Review Vol. 20, No. 4 (July, 1983), pp. 377 - 383.

(8) Katayama, K. et al., Development of Rotor Dynamics Analysis System Considering Control System, Mitsubishi Heavy Industries Ltd. Technical Review, Vol. 26, No. 3 (May, 1989), pp. 253 - 256.

(9) Morii, S. et al., Study on Shape Control and Vibration Absorber of Strip in Steel Process Line, LDIA 2005 (Kobe-Awaji, Japan, Sept. 25-28, 2005), pp. 516-519. 